Original Research Paper

\title{
Environmental Pollution by Heavy Metals in the Gold Mining Region of East Cameroon
}

\author{
${ }^{1,2.3}$ Dallou Guy Blanchard, ${ }^{1,2}$ Ngoa Engola Louis, ${ }^{2,4}$ Abdourahimi, \\ ${ }^{1}$ Bongue Daniel, ${ }^{2,4}$ Saïdou, ${ }^{2}$ Ndjana Nkoulou II Joseph Emmanuel, \\ ${ }^{5}$ Kankeu Boniface and ${ }^{1}$ Kwato Njock Moïse Godfroy \\ ${ }^{I}$ Centre for Atomic Molecular Physics and Quantum Optics, University of Douala, P.O. Box 8580 Douala, Cameroon \\ ${ }^{2}$ Nuclear Technology Section, Institute of Geological and Mining Research, P.O. Box 4110 Yaounde, Cameroon \\ ${ }^{3}$ Institut National de Recherche en Sciences Exactes et Naturelles, P.O Box 2400 Brazzaville, Congo \\ ${ }^{4}$ Nuclear Physics Laboratory, Faculty of Science, University of Yaounde I, P.O. Box 812 Yaounde, Cameroon \\ ${ }^{5}$ Laboratory of Mineral Ore Processing, Institute of Geological and Mining Research, P.O. Box 4110 Yaounde, Cameroon
}

Article history

Received: 27-07-2018

Revised: $27-08-2018$

Accepted: 03-11-2018

Corresponding Author:

Saïdou

Nuclear Technology Section, Institute of Geological and Mining Research, P.O. Box 4110 Yaounde, Cameroon Tel: (+237) 674174473

E-mail: saidous2002@yahoo.fr ous.saidou@gmail.com

\begin{abstract}
The main objective of this study is to assess the level of heavy metals pollution in soil samples collected around gold mines located in Betaré Oya (BO) and Batouri (BA) in Eastern Cameroon. Elemental analysis of soil samples was carried out using Quant'X EDXRF spectrometer. Its sensitivity and accuracy were increased by using the Fundamental Parameter approach for quantification of the results. Analysis results showed high content of iron $(39300 \pm 200 \mathrm{ppm})$, the presence of manganese $(730 \pm 70 \mathrm{ppm})$, arsenic $(4 \pm 2 \mathrm{ppm})$, zirconium $(314 \pm 4 \mathrm{ppm})$ and lead ( $79 \pm 9 \mathrm{ppm})$ as compared to worldwide average upper continental crust (UCC). The mean Enrichment Factors (EF) decrease as $\mathrm{Pb}>\mathrm{As}>\mathrm{Zr}>\mathrm{Mn}>\mathrm{Fe}>\mathrm{Y}>\mathrm{Ga}>\mathrm{Zn}>\mathrm{Cu}>\mathrm{Ni}>\mathrm{Rb}>\mathrm{Sr}>\mathrm{Sn}>\mathrm{Ba}$ in agreement with the Contamination Factors (CF). The values of pollution load index (PLI) were found to be low in all the studied samples and indicate that the studied sites in Bétaré Oya and Batouri are in low pollution status regarding the total of the studied metals. Results of this study pointed out that soils examined in the gold mining areas of Eastern Cameroon are polluted by heavy metals. It is therefore important that measures should be geared towards strengthening the monitoring of mining areas to stem down the level of contamination of soil. Phytoremediation of sites after closing open pits or the biogeosystem method would be a suitable way of regulation of the studies areas.
\end{abstract}

Keywords: Gold Mine, X-Ray Fluorescence, Heavy Metals, Enrichment Factor, Pollution Load Index

\section{Introduction}

Incorrect outdated industrialization is one of the main causes of worldwide environmental pollution. Among the various pollutants, heavy metals are the more serious in our natural environment (Caeiro et al., 2015; Emmanuel et al., 2014; Pawan, 2012). The study of heavy metals deposition and accumulation is a universal problem because of the negative consequences that heavy metals in soils may have on human health and on the environment (Likuku et al., 2013). At low fodder supply for cattle-keeping, in pastures in the vicinity of the mining area the heavy metals from plants and soils could enter the digestive tract of grazing livestock subsequently contaminating the humans food chain. Soils are usually regarded as the ultimate sink for heavy metals discharged into the environment (Banat et al., 2005; Nazari and Razmara, 2014; Ezekiel and Ayinde, 2015; Adedeji et al., 2014). In addition to the geochemical background, the amount of metals in soil may be increased by human activities and atmospheric deposition. The problem of soil pollution by heavy metals has received increasing attention in the last few decades in both developing and developed countries throughout the world.

Several gold mining sites are registered in Eastern Cameroon located at Bétaré Oya, Batouri, Kette, etc. including small, medium and large scale mining. In some 
of these sites, gold is still collected from soils surface in rivers. The levels of heavy metals resulting from industrial activities such as mining and mineral processing have not been evaluated in almost all the mines in Cameroon.

In the present study, soil samples were collected from a depth of $0-5 \mathrm{~cm}$ in the areas of Bétaré Oya and Batouri, because of mining residues discharged in the immediate environment. These residues discharged without any treatment may lead to the contamination of surface and groundwater, sediments, soils and plants.

\section{Materials and Methods}

\section{Description and Geology of Study Areas}

Bétaré Oya and Batouri are two cities located at about $176 \mathrm{~km}$ and $135 \mathrm{~km}$ respectively from Bertoua, the regional capital of East-Cameroon. The study was conducted around the gold mines of Bétaré Oya (latitudes $5^{\circ} 35^{\prime} 00^{\prime \prime}$ to $5^{\circ} 39^{\prime} 00^{\prime \prime} \mathrm{N}$; longitudes $14^{\circ} 04^{\prime} 00^{\prime \prime}$ to $14^{\circ} 07^{\prime} 00^{\prime \prime} \mathrm{E}$ ) and Batouri (latitudes $4^{\circ} 35^{\prime} 00^{\prime \prime}$ to $4^{\circ} 38^{\prime} 00^{\prime \prime} \mathrm{N}$; longitudes $14^{\circ} 24^{\prime} 00^{\prime \prime}$ to $14^{\circ} 26^{\prime} 00^{\prime \prime} \mathrm{E}$ ) as shown in Fig. 1.

The study areas are dominated by the remains of artisanal gold mining marked by the presence of several abandoned open pits scattered in areas of ancient or recent gold mining. These pits are of various sizes that can reach $200 \mathrm{~m}^{2}$ and often contain stagnant water. This situation leads to a severe disturbance of the land surface and the disappearance of the cultivable land and gallery forest. In addition oil and fuel used for the engines, the vestiges of abandoned machines, rusty empty barrels and plastic tins, production of large amounts of fined-grained material due to the digging of numerous pits in river sediments tend to increase the risk of contamination (Penaye and Hell, 2013). The study areas are undergoing intense surface gold mining since 2006.

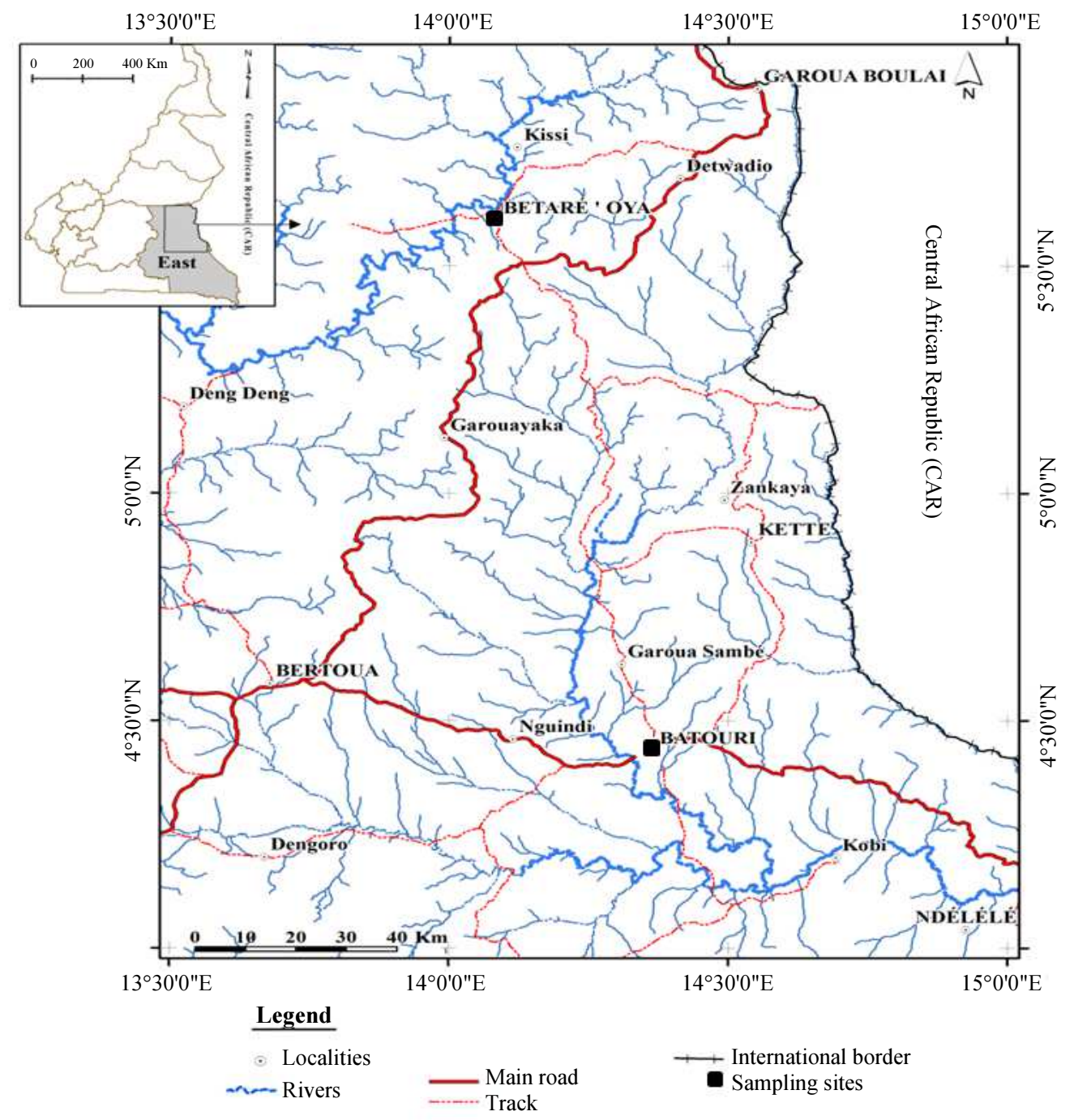

Fig. 1: Location of the gold mining areas of Batouri (Kambélé) and Bétaré Oya in Eastern Cameroon 
Batouri and Bétaré Oya are respectively subject to the influence of hot and humid equatorial climate of classical Guinean type and tropical climate of sahelian Guinean type. There is a transition between the equatorial forest to the south and the savannah to the north. The climatic conditions of the study areas are (i) a rainy season from April to October, (ii) dry season from November to March and (iii) absolute low water in March. The annual average rainfall at Bétaré Oya is $1590 \mathrm{~mm}$ and approximately $1509 \mathrm{~mm}$ at Batouri (Penaye and Hell, 2013; CTFC, 2012). Most of the land is covered with sparse grass, shrubs and trees. According to the villagers, agricultural activities such as crop cultivation are in decline, while artisanal gold mining is still practiced.

The regional geology is dominated by the Neoproterozoic volcano-sedimentary rocks, metamorphosed under low-to medium-grade conditions and cross-cut by the Pan-African granitoids (Suh et al., 2006; Tehna et al.; 2015; Yakeu et al., 2016). Gold occurs as small particles disseminated within the quartz matrix and along microfractures within the veins. These veins have as much as $54 \mathrm{ppm}$ gold. The quartz veins show variable textures. This pervasive variation in quartz vein textures is associated to the different generations and recrystalization events commonly exhibited by quartz crystals. Hand specimen samples for some of these quartz veins show visible gold associated with disseminated sulphides and oxides (Suh et al., 2006). The quartzite show well preserved primary sedimentary structures such as current marks, indicating the flow direction, together with oblique cross stratification and load casts (Albert et al., 2012). The soil in the area is predominantly acrisols, alisols, plinthosols, acid soil with clay-enriched lower horizon and low saturation of bases.

\section{Sampling and Conditioning}

Sampling was based on the proximity to potential pollution sources of mine (mining residues) due to processing, the presence of water flows and other activities (agricultural, livestock...). Thirty two (32) soil samples were collected within selected areas of the gold mining sites of Bétaré Oya and Batouri using a systematic random sampling basis because of the irregular form of the study areas. Twenty four (24) soil samples $(0-5 \mathrm{~cm})$ were collected in Bétaré Oya within $10 \mathrm{~km}$ radius from the perimeter of gold mining sites and eight (8) soil samples $(0-5 \mathrm{~cm})$ collected within $2 \mathrm{~km}$ radius from the perimeter of gold mining site of Kambele in Batouri. Each sample, with a total fresh mass of about $2 \mathrm{~kg}$, was made up of a composite of material from 5 holes distributed at the
4 corners and centre of a $1 \mathrm{~m}^{2}$ surface area with a maximum depth sampled of $5 \mathrm{~cm}$ (Dallou et al., 2017). The soil samples were collected using a reusable stainless steel shovel and trowel. Each sample were stored in sealed plastic containers and carefully labeled. To avoid contamination between samples, the samplers were cleaned after each sample drawing. The soil samples were taken to the Institute of Geological and Mining Research (IRGM), Yaoundé for elemental analysis.

In the laboratory, heavy metal concentrations were determined in accordance with protocols at the Nuclear Technology Section of IRGM. Large particles were removed from the samples and the remaining sample dried in a UK Gallenkamp Hotbox Oven with fan size 3 , for 2 days at $70^{\circ} \mathrm{C}$. The samples were then pulverized using a German Fritsch Pulverisette with speed up to $60 \mathrm{rpm}$, sieved at about $2 \mathrm{~mm}$ diameter. A mixture of two grams (soil $+10 \%$ of Licowax $\mathrm{C}$ Micropowder, PM, Hoechstwax) for each sample was weighed on a Sartorius analytical balance (TE 153S) with a precision of $0.001 \mathrm{~g}$, homogenized and ground in an agate mortar to obtain micron-sized diameters that were used to press pellets of $32 \mathrm{~mm}$ diameter under 20T using a Manual VANEOX 25t Press. More details on sample preparation are given in Abdourahimi et al. (2016).

\section{Analysis}

Analyses of soil pellets were carried out by EDXRF Quant'X spectrometer. Spectra acquisition and quantification were performed using Wintrace 4.1. The Fundamental Parameter (FP) method was used for quantification. Combined analytical uncertainty included the calibration of EDXRF Quant'X, instability of the electronics, counting statistics and sample preparation. The unknown elements were estimated as $\mathrm{SiO}_{2}: 96 \%$. The Certified Reference Materials (CRMs) NIST 2704, NIST 2709, NIST 2710, PACS 1 were used to make calibration for soil analysis (Abdourahimi et al., 2016). The Z-score values recorded are given in Table 1 . The heavy metals concentrations in the gold mining soil samples were subjected to Spearman's significant correlation analysis using statistical software $\mathrm{R}$ version 3.3.1 to determine the relationship and caracteristic between the different heavy metals.

\section{Data Processing}

The results obtained were used to determine the Contamination Factor (CF), degree of contamination (Cdeg), Enrichment Factor (EF) and geoaccumulation Index (Igeo) of the metals in the studied environment. 


\begin{tabular}{|c|c|c|c|c|c|}
\hline Element & $\begin{array}{l}\text { Analyte } \\
\text { concentration (ppm) }\end{array}$ & Standard dev. & $\begin{array}{l}\text { Assigned value of } \\
\text { the analyte (ppm) }\end{array}$ & Standard dev. & $Z$ score \\
\hline $\mathrm{Fe}(\mathrm{g} / \mathrm{kg})$ & 6.064 & 0.254 & 6.100 & 0.0327 & -0.09 \\
\hline $\mathrm{Br}$ & 11.780 & 0.380 & 10.400 & 1.3500 & 0.79 \\
\hline $\mathrm{Ca}$ & 0.340 & 0.200 & 0.283 & 0.0554 & 0.69 \\
\hline $\mathrm{Cu}$ & 16.600 & 2.500 & 18.000 & 2.6300 & -0.50 \\
\hline Mn & 279.000 & 23.940 & 226.000 & 16.7000 & 2.21 \\
\hline $\mathrm{Ni}$ & 5.250 & 0.520 & 8.760 & 1.5290 & -2.31 \\
\hline $\mathrm{Pb}$ & 14.600 & 2.240 & 26.300 & 3.4100 & -3.03 \\
\hline $\mathrm{Rb}$ & 52.810 & 0.390 & 41.800 & 2.2200 & 1.93 \\
\hline $\mathrm{Sb}$ & 0.730 & 0.510 & 0.638 & 0.0858 & 0.56 \\
\hline $\mathrm{Sr}$ & 65.980 & 1.610 & 53.700 & 3.8700 & 2.60 \\
\hline $\mathrm{Y}$ & 11.330 & 0.510 & 10.800 & 2.3000 & 0.44 \\
\hline $\mathrm{Zn}$ & 45.450 & 2.640 & 47.800 & 5.3100 & -0.55 \\
\hline $\mathrm{Zr}$ & 384.850 & 11.080 & 387.000 & 65.8000 & -0.06 \\
\hline
\end{tabular}

\section{Contamination Factor and Degree of Contamination}

To assess the level of heavy metals contamination in gold mining sites and surroundings, CF and Cdeg were calculated using the method presented by Rastmanesh et al. (2010). This method is commonly used by numerous researchers as an indicator of contamination in sediments and soils (Ghadimi, 2014; Banu et al., 2013; Iqbal et al., 2013; Abhijit and Ramkrishna, 2017). CF is determined by using the following Equation 1:

$$
C^{x} F=\frac{C_{o}^{x}}{C_{n}^{x}}
$$

where, $C^{x} F$ represent the contamination factor of the element of interest, $C_{o}^{x}$ is the concentration of the element in the sample, $C_{n}^{x}$ is the background concentration. In the present study the average Upper Continental Crust (UCC) was used (Taylor and Mclennan, 1985; Esser and Turekian, 1993; Jochum et al., 1993). $C^{x} F$ is defined according to four categories given as follows: $<1=$ low contamination factor, $1-3=$ moderate contamination factors, 3-6 = considerable contamination factors and $>6$ $=$ very high contamination factor (Rastmanesh et al., 2010; Likuku et al., 2013; Sadhu et al., 2012).

The degree of contamination ( $\mathrm{Cdeg}$ ) is the sum of CFs. It allows the assessment of the polymetallic contamination for each sampling site (Halim et al., 2014; Tariq et al., 2018). It is calculated according to the following Equation 2:

$$
C_{\mathrm{deg}}=\sum_{x=1}^{N} C^{x} F
$$

Four categories have been defined for Cdeg as follows: $<8=$ low degree of contamination, $8-16=$ moderate degree of contamination, $16-32=$ considerable degree of contamination and $>32=$ very high degree of contamination (Rastmanesh et al., 2010).

\section{Pollution Load Index}

The Pollution Load Index (PLI) is used to comprehensively evaluate the pollution effect of study metals and for each site, it is defined as follows (Caeiro et al., 2015; Feifei et al., 2015):

$$
P L I=\sqrt[n]{C F_{1} \times C F_{2} \times C F_{3} \ldots \times C F_{n}}
$$

where, $n$ is the number of metals studied and $C F$ is the contamination factor calculated as described in an earlier equation. The $P L I$ value greater than 1 is polluted, while less than 1 indicates no pollution (Tariq et al., 2018; Khan et al., 2017; Krika and Krika, 2017).

\section{Enrichment Factor}

$\mathrm{EF}$ of an element is based on normalizing a measured element against a reference element. It enables to differentiate heavy metals originating from anthropogenic sources and those of natural sources (Emmanuel et al., 2014; Salati and Moore, 2010). The enrichment factor was calculated using the formula used by number of authors (Abhijit and Ramkrishna, 2017; Tariq et al., 2018; Smuc et al., 2015; Zahran et al., 2015; Jiao et al., 2015) and given by the following Equation 4 :

$$
E F=\frac{\left(C_{n} / C_{\text {ref }}\right)_{\text {sample }}}{\left(B_{n} / B_{\text {ref }}\right)}
$$

where, $C_{n}$ (sample) is the concentration of the examined element in the environment, $C_{r e f}$ (sample) is the concentration of the examined element in the reference environment, $B_{n}$ is the concentration of the reference element in the environment and $B_{r e f}$ is the concentration of the reference element in the reference environment. Iron $(\mathrm{Fe})$ was used as the reference element in the crust 
(Abhijit and Ramkrishna, 2017; Taylor and Mclennan, 1985). Five contamination categories were recognized on the basis of the enrichment factor. They are given by: EF $<2=$ minimal enrichment, $\mathrm{EF}=2-5$ moderate enrichment, $\mathrm{EF}=5-20$ significant enrichment, $\mathrm{EF}=20-40$ very high enrichment and EF $>40$ extremely high enrichment (Emmanuel et al., 2014; Yongming et al., 2016).

\section{Geoaccumulation Index}

The Geoaccumulation Index (Igeo), was introduced by Müller (1969) to assess the level of metal accumulation in the sediments and has been used by several researchers for various studies (Abhijit and Ramkrishna, 2017; Zahra et al., 2014; Nowrouzi and Pourkhabbaz, 2014). It is mathematically expressed as follows:

$$
\text { Igeo }=\log _{2}\left(\frac{C_{n}}{1.5 \times B_{n}}\right)
$$

where, $C_{n}$ represents the measured concentration of heavy metal in the soil, $B_{n}$ is the geochemical background concentration of the heavy metal. The factor 1.5 is incorporated in the relationship to account for possible variation in background data due to lithogenic effect. The geoaccumulation index (Igeo) scale consists of seven grades ranging from unpolluted to highly polluted as given below (Emmanuel et al., 2014; Müller, 1969; Kabir et al., 2011):

$<0=$ practically unpolluted, $0-1=$ unpolluted to moderately polluted, 1-2 = moderately polluted, $2-3=$ moderately to strongly polluted, $3-4=$ strongly polluted, $4-5=$ strongly to extremely polluted and $>5=$ extremely polluted.

\section{Results and Discussion}

\section{Heavy Metals Concentrations}

The mean concentrations of elements in soil samples collected in gold mining sites of Bétaré Oya and Batouri decreases as: $\mathrm{Fe}$ $>\mathrm{Mn}>\mathrm{Zr}>\mathrm{Pb}>\mathrm{Rb}>\mathrm{Zn}>\mathrm{Sr}>\mathrm{Ba}>\mathrm{Y}>\mathrm{Cu}>\mathrm{Ga}>\mathrm{Ni}>\mathrm{As}>\mathrm{Br}>\mathrm{Sn}$.

High concentrations of iron $(\mathrm{Fe})$ have been observed in soil samples collected from sites of Bétaré Oya. They range from 28131 to $55780 \mathrm{ppm}$ with a mean of $43179 \pm 315 \mathrm{ppm}$ at Bétaré Oya (Table 2) and from 28328 to $30777 \mathrm{ppm}$ with a mean $29552 \pm 204 \mathrm{ppm}$ at Batouri (Table 3). Toxic effects related to iron can appear if concentrations in the human body are higher that the critical value $(50000 \mathrm{ppm})$ indicated by the WHO (World Health Organization), affecting negatively several organs particularly in children (Baby et al., 2010; Chiroma et al., 2014). The highest concentration (55780 $\mathrm{ppm}$ ) of $\mathrm{Fe}$ recorded in $\mathrm{BO} 3$ site located behind the
Public School of Bétaré Oya is slightly higher than the critical value indicated above. High concentrations of Manganese $(\mathrm{Mn})$ compared to the worldwide average Upper Continental Crust (UCC) in some sites were measured. These concentrations range from 498.8 to $1169.3 \mathrm{ppm}$ with a mean of $840 \pm 44 \mathrm{ppm}$ at Bétaré Oya and from 402.3 to $476.1 \mathrm{ppm}$ with a mean $439 \pm 25$ at Batouri. However, these concentrations are lower than critical value (2000 ppm) authorized by the WHO (1996) in all sites (Table 2). ATSDR (2012) and, more recently, Lucchini et al. (2015) reviewed the toxicity of manganese. These studies showed that exposure to concentrations higher than this value can cause toxic effects primarily on the brain and central nervous system. The mean concentrations of $\mathrm{Fe}$ and $\mathrm{Mn}$ in this study area exceeded concentrations reported in similar studies on heavy metals contamination associated with gold mining in Sudan (Mushtaha et al., 2017) and Ghana (Crentsil and Anthony, 2016). The concentrations of lead (Pb) ranged from 28.8 to $293.4 \mathrm{ppm}$ with a mean of $105 \pm 17 \mathrm{ppm}$ at Bétaré Oya and from 0.0 to $26.7 \mathrm{ppm}$ with a mean value of $13.4 \pm 5$ at Batouri. In most sites they exceeded worldwide average value, but are lower than the critical value ( $100 \mathrm{ppm}$ ) authorized by the WHO (1996), excepted mining site located behind the Government High School of Bétaré Oya (BO4) (Table 2). $\mathrm{Pb}$ presents a variety of dangers because the $\mathrm{Pb}$ accumulated in the human body affects negatively several organs: bones, liver, kidney, brain, lung and central nervous system (Castro-Gonzalez and MendezArmenta, 2008). Although toxicity of lead from industrial settings has been relatively controlled, it remains a pervasive toxicant worldwide (Arif et al., 2015; Azizi and Azizi, 2010). In comparison with other similar studies, the mean concentration of $\mathrm{Pb}$ in soil of study area was significantly higher than the concentrations reported in Sudan, Ghana and South Africa, respectively by Mushtaha et al. (2017), Crentsil and Anthony (2016) and Caspah et al. (2016), in addition, this concentration was also higher than obtained in the studies carried out by Feifei et al. (2015) and Sijin et al. (2015), respectively around a gold mine and Zinc-Lead mining area in China (Table 4). Concentrations of Arsenic (As) range from 0.0 to 16.2 ppm with a mean value of $4.6 \pm 4$ ppm (Table 2) at Bétaré Oya and from 0.0 to $5.6 \mathrm{ppm}$ with a mean value of $3 \pm 2.4$ at Batouri (Table 3). They exceeded the worldwide average value in some sites. The highest concentration of As was recorded in a mining site abandoned of Bétaré Oya (BO5) while in sites BO3, BO4 and BA2 (Narké crossroads, Batouri), they were below the detection limit. This high value in $\mathrm{BO} 5$ site could be explained by the presence of vestiges abandoned machines and mineral residues discharged in the pits scattered. Despite being the 20th most abundant element in the earth's crust, As ranks highest on the list of hazardous substances toxic to 
public health (Arif et al., 2015). Inorganic arsenic is considered as a human carcinogen (cancer-causing agent) by the U.S. and exposure to arsenic has been linked to increased incidence of irritation of mucous membranes and lung cancer (WHO, 1996; Qian et al., 2014; Mo et al., 2016). In general, As concentrations in all the sites are lower than normal value (20 ppm) authorized by the WHO. Concentrations of copper $(\mathrm{Cu})$ ranged from 13.1 to $28.5 \mathrm{ppm}$ with a mean of $21 \pm 7 \mathrm{ppm}$ (Table 2) at Bétaré Oya while in sites in sites BA1 et BA2 of Batouri, they were below the detection limit. In humans $\mathrm{Cu}$ is necessary for their development, but may be toxic when its concentration exceeds the reference value (100 ppm) given by the WHO for soils (Chiroma et al., 2014; Ran et al., 2017; Sabah et al., 2012)). The observed concentration of $\mathrm{Cu}$ did exceed the earth crust threshold value prescribed in soil for $\mathrm{BO} 3$ site, but not for others. The concentrations of zinc $(\mathrm{Zn})$ ranged from 20.3 to 87.3 ppm with a mean of $45 \pm 10$ ppm (Table 2) at Bétaré Oya and from 24.6 to $29.3 \mathrm{ppm}$ with a mean value of $27 \pm 6$ at Batouri (Table 3). The observed concentrations of $\mathrm{Zn}$ did not exceed the worldwide average value prescribed in soil except for BO5 site of Bétaré Oya. Copper $(\mathrm{Cu})$ and zinc $(\mathrm{Zn})$ provide clear examples, both being essential for normal metabolism and both can be toxic in high concentrations (Verdejo et al., 2016; USEPA, 2013). When the quantities of $\mathrm{Cu}$ and $\mathrm{Zn}$ in the body increase they become toxic, which can result in damaged and malfunctioning human organs (USEPA, 2013; Bost et al., 2016; Fraga, 2005; Tobias et al., 2013). The level of Zn in this study area was higher than the concentrations found in studies on soils around gold mine in China (Feifei et al., 2015) and Sudan (Mushtaha et al., 2017) but lower than $\mathrm{Zn}$ concentration (112.3 ppm) reported in Zinc-Lead mining area in China (Sijin et al., 2015).
Concentrations of $\mathrm{Zr}$ ranged from 128.5 to $182.1 \mathrm{ppm}$ with a mean of $149 \pm 18 \mathrm{ppm}$ (Table 2) at Bétaré Oya, below the average value in the upper continental crust (190 ppm) while at Batouri, they were ranged from 616.7 to $832.7 \mathrm{ppm}$ with a mean of $724.7 \pm 32 \mathrm{ppm}$ (Table 3 ) above the average value in the upper continental crust. The highest concentrations of $\mathrm{Zr}$ were recorded in Batouri (BA1 and BA2) sites. In other sites concentrations did not exceed the average in the earth crust. In soil, $\mathrm{Zr}$ is more than twice as abundant as copper and zinc and has ten times more abundance that lead (Shahid et al., 2013). Its geochemistry is dominated by its lithophilic nature. Although data are scarce, it appears that $\mathrm{Zr}$ have low toxicity to organisms (Shahid et al., 2013). Concentrations of gallium $(\mathrm{Ga})$ ranged from 5.8 to 18.1 ppm with a mean of $10.8 \pm 5 \mathrm{ppm}$ at Bétaré Oya and from 8.1 to $17.5 \mathrm{ppm}$ with a mean value of $12.8 \pm 4.3 \mathrm{ppm}$ at Batouri. Observed concentrations of Ga did not exceed the worldwide average value prescribed in soil in most sites except for BO5 and BA1 (Kambélé, METALICOM Company) sites. Gallium causes increased unbound $\mathrm{Fe}$ owing to its ability to substitute for $\mathrm{Fe}$ in numerous moieties involved in vital cellular functioning (Auger et al., 2013; Bignucolo et al., 2013). It is known to be toxic at high concentrations (Sujeenthar et al., 2017). The concentrations of yttrium (Y) ranged from 15.8 to 26.3 ppm with a mean of $20 \pm 7$ ppm at Bétaré Oya and from 11.2 to $15.5 \mathrm{ppm}$ with a mean value of $13.4 \pm 4 \mathrm{ppm}$ at Batouri. The highest concentration of $\mathrm{Y}$ was recorded in Ali-Bachir mining site located at Bétaré Oya (BO1). In other sites, concentrations did not exceed the reference value considered in the soil. As a heavy metal, yttrium is not entirely free of toxicity. It can be a threat to the liver when its concentration exceeds the safe limits in the human body (He, 2013).

Table 2: Summary statistics of heavy metals $(\mathrm{ppm})$ concentrations in gold mining sites of Bétaré Oya $(\mathrm{n}=24)$

\begin{tabular}{lcrrrrl}
\hline Elements & Minimum & Maximum & \multicolumn{1}{c}{ Mean } & Std. Deviation & Worldwide average* & $\begin{array}{l}\text { Maximum permissible } \\
\text { Level in soil }\end{array}$ \\
\hline $\mathrm{Mn}$ & 498.9 & 1169.3 & 840.0 & 44.0 & 600.0 & $2000^{\mathrm{a}}$ \\
$\mathrm{Fe}$ & 28131.0 & 55780.0 & 43179.0 & 315.0 & 35000.0 & $50000^{\mathrm{a}}$ \\
$\mathrm{Ni}$ & 6.8 & 10.1 & 9.0 & 4.5 & 20.0 & $50^{\mathrm{a}}, 40^{\mathrm{b}}$ \\
$\mathrm{Ba}$ & - & 45.2 & 17.1 & 7.3 & 550.0 & N.A \\
$\mathrm{Cu}$ & 13.1 & 28.5 & 21.0 & 7.0 & 25.0 & $100^{\mathrm{a}}, 30^{\mathrm{b}}$ \\
$\mathrm{Zn}$ & 20.3 & 87.3 & 45.0 & 10.0 & 71.0 & $300^{\mathrm{a}}$ \\
$\mathrm{Ga}$ & 5.8 & 18.1 & 10.8 & 5.0 & 17.0 & N.A \\
$\mathrm{As}$ & - & 16.2 & 4.6 & 4.0 & 1.5 & N.A \\
$\mathrm{Br}$ & - & 2.2 & 1.3 & 1.1 & N.A & N.A \\
$\mathrm{Rb}$ & 34.2 & 61.4 & 46.8 & 10.0 & 112.0 & N.A \\
$\mathrm{Sr}$ & 23.1 & 54.5 & 33.3 & 9.0 & 350.0 & N.A \\
$\mathrm{Y}$ & 15.8 & 26.3 & 20.0 & 7.0 & 22.0 & N.A \\
$\mathrm{Zr}$ & 128.5 & 182.1 & 149.0 & 18.0 & 190.0 & $100^{\mathrm{a}, \mathrm{b}}$ \\
$\mathrm{Pb}$ & 28.8 & 293.4 & 105.0 & 17.0 & 20.0 & N.A \\
$\mathrm{Sn}$ & - & 0.5 & 0.1 & 0.1 & 5.5 & . \\
\hline $\mathrm{N}$ & & & & & &
\end{tabular}

N.A $=$ not available, $*$ worldwide average upper continental crust (Taylor and Mclennan, 1985; Esser and Turekian, 1993; Jochum et al., 1993), ${ }^{a}$ Chiroma et al. (2014) and ${ }^{b}$ Tobias et al. (2013): The maximum acceptable limits of heavy metals in soils established by standard regulatory bodies such as World Health Organization (WHO), Food and Agricultural Organization (FAO) and the European Union. 
Table 3: Summary statistics of heavy metals (ppm) concentrations in gold mining sites of Batouri $(\mathrm{n}=8)$

\begin{tabular}{lllllll}
\hline Elements & Minimum & Maximum & Mean & Std. Deviation & Worldwide average* & $\begin{array}{l}\text { Maximum permissible } \\
\text { Level in soil }\end{array}$ \\
\hline $\mathrm{Mn}$ & 402.3 & 476.1 & 439 & 25 & 600 & $2000^{\mathrm{a}}$ \\
$\mathrm{Fe}$ & 28328 & 30777 & 29552 & 204 & 35000 & $50000^{\mathrm{a}}$ \\
$\mathrm{Ni}$ & 6 & 7.2 & 6.6 & 3 & 20 & $50^{\mathrm{a}}, 40^{\mathrm{b}}$ \\
$\mathrm{Ba}$ & 5.0 & 64.3 & 34.7 & 8 & 550 & N.A \\
$\mathrm{Cu}$ & - & - & - & - & 25 & $100^{\mathrm{a}}, 30^{\mathrm{b}}$ \\
$\mathrm{Zn}$ & 24.6 & 29.3 & 27 & 6 & 71 & $300^{\mathrm{a}}$ \\
$\mathrm{Ga}$ & 8.1 & 17.5 & 12.8 & 4.3 & 17 & N.A \\
$\mathrm{As}$ & - & 5.9 & 3 & 2.4 & 1.5 & 20 \\
$\mathrm{Br}$ & 2.3 & 3.3 & 2.8 & 2 & N.A & N.A \\
$\mathrm{Rb}$ & 23.4 & 27.2 & 25.3 & 6 & 112 & N.A \\
$\mathrm{Sr}$ & 36.8 & 56.8 & 46.8 & 8 & 350 & N.A \\
$\mathrm{Y}$ & 11.2 & 15.5 & 13.4 & 4 & 22 & N.A \\
$\mathrm{Zr}$ & 616.7 & 832.7 & 724.7 & 32 & 190 & N.A \\
$\mathrm{Pb}$ & - & 26.7 & 13.4 & 5 & 20 & $100^{\mathrm{a}, \mathrm{b}}$ \\
$\mathrm{Sn}$ & 1.1 & 1.9 & 1.5 & 1.4 & 5.5 & N.A \\
\hline
\end{tabular}

Table 4: Comparison of average heavy metal concentrations with those of similar studies carried out in other countries

\begin{tabular}{|c|c|c|c|c|c|c|c|c|c|c|c|c|}
\hline \multirow[b]{2}{*}{ Country } & \multicolumn{12}{|c|}{ Mean concentration (ppm) } \\
\hline & $\mathrm{Hg}$ & As & $\mathrm{Cd}$ & $\mathrm{Pb}$ & $\mathrm{Zn}$ & $\mathrm{Cu}$ & $\mathrm{Ni}$ & Co & $\mathrm{Cr}$ & $\mathrm{Fe}$ & $\mathrm{Mn}$ & Reference \\
\hline \multirow[t]{2}{*}{ China } & $0.17 \pm$ & $7.11 \pm$ & $0.33 \pm$ & $28.3 \pm$ & $39.7 \pm$ & $12.9 \pm$ & - & - & - & - & - & Feifei et al. \\
\hline & 0.064 & 1.32 & 0.023 & 4.6 & 3.5 & 2.1 & & & & & & (2015) \\
\hline \multirow[t]{2}{*}{ China } & $0.12 \pm$ & $10.6 \pm$ & $0.24 \pm$ & $39.2 \pm$ & $112.3 \pm$ & $30 \pm 22$ & $28.4 \pm$ & - & $59.8 \pm$ & - & - & Sijin et al. \\
\hline & 0.09 & 6.50 & 0.29 & 19.5 & 70.6 & & 13.8 & & 25.6 & & & $(2015)$ \\
\hline \multirow[t]{2}{*}{ China } & $1.62 \pm$ & $6.90 \pm$ & $0.65 \pm$ & $109 \pm$ & $155 \pm$ & $58.30 \pm$ & $54.20 \pm$ & $20.17 \pm$ & $189.9 \pm$ & - & - & Qian et al. \\
\hline & 2.24 & 3.10 & 0.71 & 145.1 & 63.7 & 21.20 & 15.20 & 5.60 & 73.7 & & & (2014) \\
\hline \multirow[t]{2}{*}{ China } & $0.12 \pm$ & $8.57 \pm$ & $0.15 \pm$ & $819.7 \pm$ & $104.2 \pm$ & $46.92 \pm$ & $28.40 \pm$ & - & $88.61 \pm$ & & & Mo et al. \\
\hline & 0.12 & 6.07 & 0.06 & 1126 & 44.8 & 21.03 & 9.43 & & 47 & - & - & $(2016)$ \\
\hline South Africa & 0.09 & 79.40 & 0.05 & 4.79 & 51.30 & 42.51 & 112.06 & 25.56 & 278.8 & - & - & $\begin{array}{l}\text { Caspah et al. } \\
(2016)\end{array}$ \\
\hline \multirow[t]{2}{*}{ Ghana } & $1.06 \pm$ & $6.83 \pm$ & $0.19 \pm$ & $19.96 \pm$ & $61.87 \pm$ & $16.03 \pm$ & $41.77 \pm$ & - & $16.88 \pm$ & $531.5 \pm$ & $445.6 \pm$ & Crentsil and \\
\hline & 0.65 & 2.42 & 0.13 & 3.11 & 16.5 & 3.22 & 13.60 & & 2.47 & 97 & 108 & Anthony (2016) \\
\hline China & 2.91 & 16 & 2.45 & 252 & 286 & 46.4 & - & - & - & - & - & $\begin{array}{l}\text { Ran et al. } \\
(2017)\end{array}$ \\
\hline Sudan & - & - & - & 12.46 & 20.85 & 19 & 15.33 & 5.2 & - & 8473 & 238.1 & $\begin{array}{l}\text { Mushtaha et al. } \\
\text { (2017) }\end{array}$ \\
\hline Oman & - & - & 5.33 & 96.82 & 964 & 3240 & 282 & 101.2 & - & 14108 & 2865 & $\begin{array}{l}\text { Sabah et al. } \\
\text { (2012) }\end{array}$ \\
\hline Cameroon & - & $4 \pm 2$ & - & $79 \pm 9$ & $40 \pm 8$ & $15 \pm 7$ & $8 \pm 4$ & - & - & $\begin{array}{l}39300 \pm \\
200\end{array}$ & $\begin{array}{l}730 \pm \\
70\end{array}$ & Present study \\
\hline
\end{tabular}

Concentrations of nickel $(\mathrm{Ni})$, Tin $(\mathrm{Sn})$, rubidium $(\mathrm{Rb})$, strontium $(\mathrm{Sr})$, barium $(\mathrm{Ba})$ and bromine $(\mathrm{Br})$ are low in the study area (Table 2 and 3 ) and do not exceed the earth crust threshold values prescribed in soil. The mean concentrations of arsenic (As) and nickel (Ni) in soil in this study area were slightly lower than the concentrations in the other countries (Table 4). Mercury $(\mathrm{Hg})$ and cadmium $(\mathrm{Cd})$ were below the detection limit in the all samples.

Contamination Factor, Degree of Contamination and Pollution Load Index of Heavy Metals in Soils

Results presented in Table 5 show that mean contamination factors of heavy metals follow a decreasing order: $\mathrm{Pb}>\mathrm{As}>\mathrm{Zr}>\mathrm{Mn}>\mathrm{Fe}>\mathrm{Y}>\mathrm{Ga}>\mathrm{Cu}>\mathrm{Zn}>\mathrm{Ni}>\mathrm{Rb}>\mathrm{Sr}>\mathrm{Sn}>\mathrm{Ba}$. Overall, the present study shows that the highest mean value of contamination factor observed is 3.95 for $\mathrm{Pb}$, i.e., a considerable contamination while contamination factors of heavy metals such as As, Zr, Mn and Fe were considered as moderates. Contamination factor for elements such as $\mathrm{Y}, \mathrm{Ga}, \mathrm{Cu}, \mathrm{Zn}, \mathrm{Ni}, \mathrm{Rb}, \mathrm{Sr}, \mathrm{Sn}$ and $\mathrm{Ba}$ is less than 1 indicating a low contamination from anthropogenic sources (Likuku et al., 2013).

The degrees of contamination of soil samples from various sites are presented in Fig. 2. Generally, values obtained for the degrees of contamination were higher than 8, meaning that samples from the sites have moderate degrees of contamination and considerable degrees of contamination for the $\mathrm{BO} 5$ and $\mathrm{BO} 4$ sites except the BA2 site of Batouri which presents a low degree of contamination as shown in Table 5. Mean degrees of contamination of all heavy metals compared to their respective degree of contamination reveal a 
moderate degree of contamination, indicating a moderate anthropogenic pollution (Abhijit and Ramkrishna, 2017). Comparison between degrees of contamination of gold mining sites shows a decreasing order as follows: $\mathrm{BO} 5>\mathrm{BO} 4>\mathrm{BA} 1>\mathrm{BO} 3>\mathrm{BO} 1>\mathrm{BO} 2>\mathrm{BA} 2$.

A similar result can also be obtained by examining the spatial variations in the PLI, by calculating the values of soils in the study area, in particular for both sites BO4 $(\mathrm{n}=11)$ and BO5 $(\mathrm{n}=14)$ that are 0.78 and 0.67 , respectively. These values were found to be low in all the studied samples and varied between 0.43 and 0.78 , indicating that the studied sites in Bétaré Oya and Batouri are in low pollution status regarding the total of the studied metals (Mmolawa et al., 2011). The soil of
Bétaré Oya (BO) indicate the higher degrees of contamination values, which mean that pollution caused by heavy metals is higher than that of Batouri (BA). The conclusion is consistent with the PLI.

\section{Enrichment Factor of Heavy Metals in Soil}

Enrichment factors of heavy metals presented in Fig. 3 decrease as follows: $\mathrm{Pb}>\mathrm{As}>\mathrm{Zr}>\mathrm{Mn}>\mathrm{Fe}>\mathrm{Y}>\mathrm{Ga}>\mathrm{Zn}>\mathrm{Cu}>\mathrm{Ni}>\mathrm{Rb}>\mathrm{Sr}>\mathrm{Sn}>\mathrm{Ba}$. Determining enrichment factor (EF) is an essential part of geochemical studies and is generally used to differentiate between metals originating from anthropogenic and geogenic sources and to assess the degree of metal contamination (Moore et al., 2009).

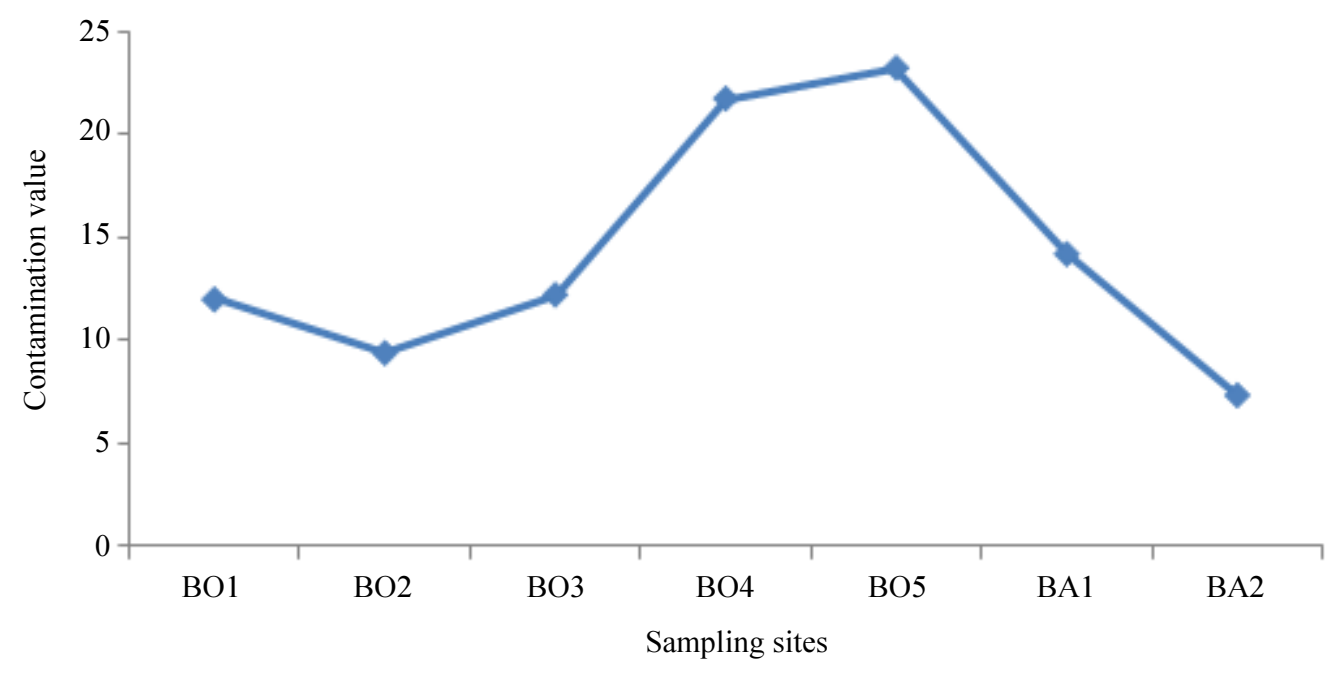

Fig. 2: Degree of Contamination of soil sampled from gold mining areas of Bétaré Oya and Batouri $(\mathrm{BO}=$ Bétaré Oya, BA = Batouri)

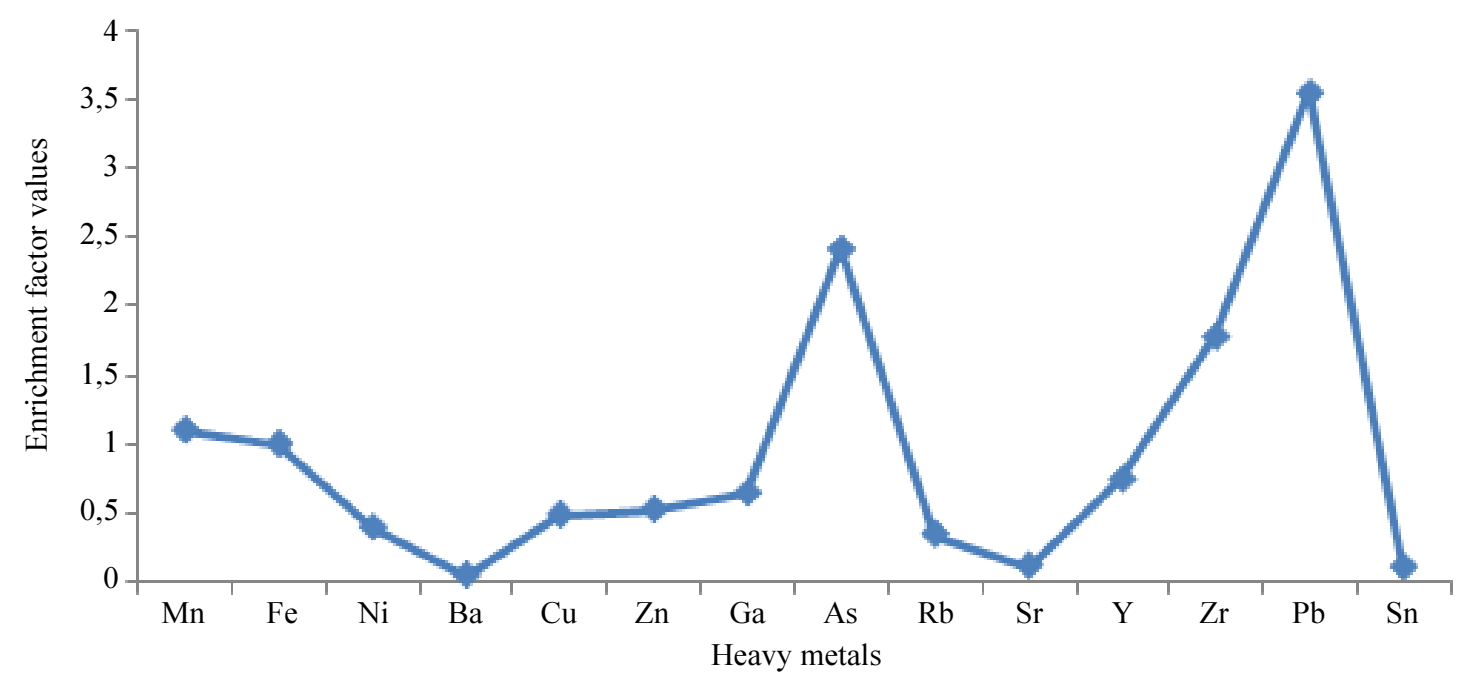

Fig. 3: Enrichment factor of soil sampled from gold mining areas of Bétaré Oya and Batouri 
Table 5: Contamination Factors (CF) and degree of contamination (Cdeg) of soil from gold mining areas of Bétaré Oya (BO) and Batouri (BA)

\begin{tabular}{|c|c|c|c|c|c|c|c|c|c|c|c|c|c|c|c|}
\hline \multirow[b]{2}{*}{ Sampling site } & \multicolumn{14}{|c|}{ Contamination Factor $(C F)$} & \multirow{2}{*}{$\begin{array}{l}\text { Contamination } \\
\text { Degree }\end{array}$} \\
\hline & $\mathrm{Mn}$ & $\mathrm{Fe}$ & $\mathrm{Ni}$ & $\mathrm{Ba}$ & $\mathrm{Cu}$ & $\mathrm{Zn}$ & $\mathrm{Ga}$ & As & $\mathrm{Rb}$ & $\mathrm{Sr}$ & $\mathrm{Y}$ & $\mathrm{Zr}$ & $\mathrm{Pb}$ & $\mathrm{Sn}$ & \\
\hline $\mathrm{BO}$ & 0.83 & 1.42 & 0.46 & 0.04 & 0.81 & 0.58 & 0.34 & 3.40 & 0.46 & 0.07 & 1.20 & 0.96 & 1.44 & 0.00 & 12.02 \\
\hline $\mathrm{BO} 2$ & 1.12 & 0.80 & 0.51 & 0.03 & 0.53 & 0.55 & 0.60 & 1.12 & 0.37 & 0.16 & 0.74 & 0.83 & 2.08 & 0.00 & 9.42 \\
\hline $\mathrm{BO} 3$ & 1.95 & 1.59 & 0.45 & 0.00 & 1.14 & 0.29 & 0.73 & 0.00 & 0.31 & 0.08 & 0.88 & 0.70 & 4.13 & 0.00 & 12.25 \\
\hline BO4 & 1.83 & 1.04 & 0.50 & 0.00 & 0.71 & 0.54 & 0.44 & 0.00 & 0.55 & 0.11 & 0.72 & 0.68 & 14.67 & 0.00 & 21.79 \\
\hline $\mathrm{BO} 5$ & 1.26 & 1.31 & 0.34 & 0.08 & 0.97 & 1.23 & 1.06 & 10.80 & 0.40 & 0.07 & 0.95 & 0.76 & 3.97 & 0.08 & 23.28 \\
\hline Mean BO & 1.40 & 1.23 & 0.45 & 0.03 & 0.83 & 0.64 & 0.63 & 3.06 & 0.42 & 0.10 & 0.90 & 0.79 & 5.26 & 0.02 & 15.76 \\
\hline BA1 & 0.79 & 0.81 & 0.30 & 0.01 & 0.00 & 0.41 & 1.03 & 3.94 & 0.21 & 0.11 & 0.70 & 4.38 & 1.33 & 0.20 & 14.23 \\
\hline BA2 & 0.67 & 0.88 & 0.36 & 0.12 & 0.00 & 0.35 & 0.48 & 0.00 & 0.24 & 0.16 & 0.51 & 3.25 & 0.00 & 0.35 & 7.36 \\
\hline Mean BA & 0.73 & 0.85 & 0.33 & 0.07 & 0.00 & 0.38 & 0.76 & 1.97 & 0.23 & 0.14 & 0.61 & 3.82 & 0.67 & 0.28 & 10.84 \\
\hline Mean values & 1.21 & 1.12 & 0.42 & 0.04 & 0.59 & 0.56 & 0.67 & 2.75 & 0.36 & 0.11 & 0.81 & 1.65 & 3.95 & 0.09 & 14.34 \\
\hline
\end{tabular}

BO2 site is located in town centre of Bétaré Oya

Table 6: Enrichment factor of heavy metals from gold mining areas of Bétaré Oya (BO) and Batouri (BA)

\begin{tabular}{|c|c|c|c|c|c|c|c|c|c|c|c|c|c|c|}
\hline \multirow[b]{2}{*}{ Sampling site } & \multicolumn{14}{|c|}{ Enrichment Factor $(E F)$} \\
\hline & $\mathrm{Mn}$ & $\mathrm{Fe}$ & $\mathrm{Ni}$ & $\mathrm{Ba}$ & $\mathrm{Cu}$ & $\mathrm{Zn}$ & $\mathrm{Ga}$ & As & $\mathrm{Rb}$ & $\mathrm{Sr}$ & $\mathrm{Y}$ & $\mathrm{Zr}$ & $\mathrm{Pb}$ & $\mathrm{Sn}$ \\
\hline $\mathrm{BO} 1$ & 0.59 & 1.00 & 0.32 & 0.03 & 0.57 & 0.41 & 0.24 & 2.39 & 0.33 & 0.05 & 0.84 & 0.67 & 1.01 & 0.00 \\
\hline $\mathrm{BO} 2$ & 1.40 & 1.00 & 0.63 & 0.04 & 0.65 & 0.68 & 0.74 & 1.39 & 0.46 & 0.19 & 0.92 & 1.03 & 2.58 & 0.00 \\
\hline $\mathrm{BO} 3$ & 1.22 & 1.00 & 0.28 & 0.00 & 0.71 & 0.18 & 0.46 & 0.00 & 0.19 & 0.05 & 0.55 & 0.44 & 2.59 & 0.00 \\
\hline BO4 & 1.76 & 1.00 & 0.48 & 0.00 & 0.68 & 0.52 & 0.42 & 0.00 & 0.53 & 0.11 & 0.69 & 0.65 & 14.05 & 0.00 \\
\hline BO5 & 0.97 & 1.00 & 0.26 & 0.06 & 0.74 & 0.94 & 0.81 & 8.27 & 0.31 & 0.05 & 0.73 & 0.58 & 3.04 & 0.06 \\
\hline Mean BO & 1.19 & 1.00 & 0.39 & 0.03 & 0.67 & 0.55 & 0.53 & 2.41 & 0.36 & 0.09 & 0.75 & 0.67 & 4.65 & 0.01 \\
\hline BA1 & 0.98 & 1.00 & 0.37 & 0.01 & 0.00 & 0.51 & 1.27 & 4.87 & 0.26 & 0.13 & 0.87 & 5.42 & 1.65 & 0.25 \\
\hline BA2 & 0.76 & 1.00 & 0.41 & 0.13 & 0.00 & 0.39 & 0.54 & 0.00 & 0.28 & 0.18 & 0.58 & 3.69 & 0.00 & 0.40 \\
\hline Mean BA & 0.87 & 1.00 & 0.39 & 0.07 & 0.00 & 0.45 & 0.91 & 2.44 & 0.27 & 0.16 & 0.71 & 4.56 & 0.83 & 0.33 \\
\hline Mean values & 1.10 & 1.00 & 0.39 & 0.04 & 0.48 & 0.52 & 0.64 & 2.42 & 0.34 & 0.11 & 0.74 & 1.78 & 3.56 & 0.10 \\
\hline
\end{tabular}

Table 6 shows that enrichment factors for Mn, Fe, Y, $\mathrm{Ga}, \mathrm{Zn}, \mathrm{Cu}, \mathrm{Ni}, \mathrm{Rb}, \mathrm{Sr}, \mathrm{Sn}$ and Ba vary between 0 and 2 , indicating the minimal enrichment in soil collected in Bétaré Oya and Batouri. For $\mathrm{Pb}$ and $\mathrm{As}$, mean enrichment factor values vary between 2 and 5 , indicating a moderate enrichment in soil (Zahran et al., 2015). Sites BO4 and BO5 of Bétaré Oya present respectively $\mathrm{Pb}$ and $\mathrm{As}$ values ranging between 5 and 20, meaning that $\mathrm{Pb}$ and $\mathrm{As}$ are the mains elements of anthropogenic loading into the soil of Betaré Oya. In BA1 site, enrichment factors of $\mathrm{Zr}$ range between 5 and 20, testifying that $\mathrm{Zr}$ is the main element of anthropogenic loading into the soil of Batouri.

\section{Geoaccumulation Index of Heavy Metals in Soils}

The degree of soils pollution can be assessed by the determination of indices such as Geoaccumulation Index (Igeo) (Nowrouzi and Pourkhabbaz, 2014). The calculated Igeo values for different samples are summarized in Table 7.

As displayed in Fig. 4, Igeo values for $\mathrm{Cu}, \mathrm{Y}, \mathrm{Ga}, \mathrm{Zn}$, $\mathrm{Ni}, \mathrm{Rb}, \mathrm{Sn}, \mathrm{Sr}$ and $\mathrm{Ba}$ fall mainly in unpolluted class $(\leq 0)$. The Igeo values for $\mathrm{Pb}$ shows that $33.33 \%$ of the sites in the all study area belong to the unpolluted class $(\leq 0), 16.67 \%$ in the unpolluted to moderately polluted class $(0-1), 33 \%$ in the moderately polluted class (1-2), while the remaining $16.67 \%$ are strongly polluted class (3-4). For As, $25 \%$ of the sites are in the unpolluted class, $50 \%$ in the moderately polluted class and $25 \%$ in the moderate to strongly polluted class. For $\mathrm{Zr}, 71.43 \%$ of the sites are included in the unpolluted class and the remaining $28.57 \%$ find themselves in the moderately polluted class. For Fe, sites mainly fall in the unpolluted class ( $85.71 \%$ of total sites) and the remaining $14.29 \%$ in the unpolluted to moderately polluted class. Finally for $\mathrm{Mn}, 71.43 \%$ of the sites are included in the unpolluted class and the remaining $28.57 \%$ belong to the unpolluted to moderately polluted class. The results in Table 7 indicate that soil samples collected in Betaré Oya locality can be categorized as follows: Unpolluted with $\mathrm{Cu}, \mathrm{Y}, \mathrm{Ga}, \mathrm{Zn}, \mathrm{Ni}, \mathrm{Rb}, \mathrm{Sn}, \mathrm{Sr}, \mathrm{Ba}, \mathrm{Fe}, \mathrm{Mn}$ and $\mathrm{Zr}$ (mean Igeo $<0)$ and moderately polluted with $\mathrm{As}$ and $\mathrm{Pb}(1<$ mean Igeo $<2$ ) (Moore et al., 2009), while these of Batouri locality can be categorized as follows: unpolluted with $\mathrm{Cu}, \mathrm{Y}, \mathrm{Ga}, \mathrm{Zn}, \mathrm{Ni}, \mathrm{Rb}, \mathrm{Sn}, \mathrm{Sr}, \mathrm{Ba}, \mathrm{Fe}$, $\mathrm{Mn}$ and $\mathrm{Pb}($ mean Igeo $<0)$ and moderately polluted with As and $\mathrm{Zr}(1<$ mean Igeo $<2)$.

\section{Elements Correlation Matrix}

Spearman correlation analysis was performed between various elements (with a level of significance: $\mathrm{p} \leq 0.01$ and $\mathrm{p} \leq 0.05$ ) for soil samples from various sites of Bétaré Oya and Batouri. The obtained results are given in Table 8. The study pointed out strong positive correlations between some elements such as $\mathrm{Cu}$ and $\mathrm{Fe}$ (0.84), $\mathrm{Pb}$ and $\mathrm{Mn}(0.96)$ at $1 \%$ significant levels. 
Dallou Guy Blanchard et al. / American Journal of Environmental Sciences 2018, 14 (5): 212.225 DOI: 10.3844/ajessp.2018.212.225

Table 7: Geoaccumulation index of heavy metals in soil from gold mining sites of Bétaré Oya (BO) and Batouri (BA) Geoaccumulation index (Igeo)

\begin{tabular}{|c|c|c|c|c|c|c|c|c|c|c|c|c|c|c|}
\hline Sampling site & $\mathrm{Mn}$ & $\mathrm{Fe}$ & $\mathrm{Ni}$ & $\mathrm{Ba}$ & $\mathrm{Cu}$ & $\mathrm{Zn}$ & $\mathrm{Ga}$ & As & $\mathrm{Rb}$ & $\mathrm{Sr}$ & $\mathrm{Y}$ & $\mathrm{Zr}$ & $\mathrm{Pb}$ & $\mathrm{Sn}$ \\
\hline $\mathrm{BO} 1$ & -0.85 & -0.08 & -1.71 & -5.07 & -0.89 & -1.36 & -2.14 & 1.18 & -1.69 & -4.51 & -0.33 & -0.65 & -0.06 & n.d \\
\hline $\mathrm{BO} 2$ & -0.42 & -0.90 & -1.57 & -5.72 & -1.51 & -1.45 & -1.33 & -0.43 & -2.01 & -3.27 & -1.02 & -0.85 & 0.47 & n.d \\
\hline $\mathrm{BO} 3$ & 0.38 & 0.09 & -1.74 & n.d & -0.40 & -2.39 & -1.04 & n.d & -2.30 & -4.27 & -0.76 & -1.09 & 1.46 & n.d \\
\hline BO4 & 0.29 & -0.52 & -1.57 & n.d & -1.09 & -1.47 & -1.78 & n.d & -1.45 & -3.76 & -1.06 & -1.15 & 3.29 & n.d \\
\hline $\mathrm{BO} 5$ & -0.25 & -0.20 & -2.15 & -4.19 & -0.64 & -0.29 & -0.50 & 2.85 & -1.91 & -4.51 & -0.66 & -0.98 & 1.40 & -4.19 \\
\hline Mean BO & -0.17 & -0.32 & -1.71 & -4.99 & -0.91 & -1.39 & -1.36 & 1.20 & -1.87 & -4.06 & -0.77 & -0.94 & 1.31 & -4.19 \\
\hline BA1 & -0.92 & -0.89 & -2.33 & -7.35 & n.d & -1.86 & -0.54 & 1.39 & -2.84 & -3.83 & -1.09 & 1.55 & -0.17 & -2.89 \\
\hline BA2 & -1.16 & -0.77 & -2.06 & -3.68 & n.d & -2.11 & -1.65 & n.d & -2.63 & -3.21 & -1.55 & 1.11 & n.d & -2.09 \\
\hline Mean BA & -1.04 & -0.83 & -2.20 & -5.52 & n.d & -1.99 & -1.10 & 1.39 & -2.74 & -3.52 & -1.32 & 1.33 & -0.17 & -2.49 \\
\hline Mean values & -0.42 & -0.47 & -1.88 & -5.20 & -0.91 & -1.56 & -1.28 & 1.25 & -2.12 & -3.91 & -0.92 & -0.29 & 1.07 & -3.06 \\
\hline
\end{tabular}

n.d = mean not defined

Table 8: Spearman correlation matrix of heavy metals in soils of Bétaré Oya and Batouri

\begin{tabular}{|c|c|c|c|c|c|c|c|c|c|c|c|c|c|c|c|}
\hline & $\mathrm{Mn}$ & $\mathrm{Fe}$ & $\mathrm{Ni}$ & $\mathrm{Ba}$ & $\mathrm{Cu}$ & $\mathrm{Zn}$ & $\mathrm{Ga}$ & As & $\mathrm{Br}$ & $\mathrm{Rb}$ & $\mathrm{Sr}$ & $\mathrm{Y}$ & $\mathrm{Zr}$ & $\mathrm{Pb}$ & $\mathrm{Sn}$ \\
\hline $\mathrm{Mn}$ & 1.00 & & & & & & & & & & & & & & \\
\hline $\mathrm{Fe}$ & 0.53 & 1.00 & & & & & & & & & & & & & \\
\hline $\mathrm{Ni}$ & 0.39 & -0.01 & 1.00 & & & & & & & & & & & & \\
\hline $\mathrm{Ba}$ & -0.66 & -0.16 & -0.33 & 1.00 & & & & & & & & & & & \\
\hline $\mathrm{Cu}$ & $0.81 *$ & $0.84 * *$ & 0.16 & -0.27 & 1.00 & & & & & & & & & & \\
\hline $\mathrm{Zn}$ & 0.00 & -0.03 & 0.12 & 0.37 & 0.19 & 1.00 & & & & & & & & & \\
\hline $\mathrm{Ga}$ & 0.14 & -0.10 & -0.68 & 0.01 & 0.12 & 0.00 & 1.00 & & & & & & & & \\
\hline As & -0.22 & -0.11 & -0.52 & 0.33 & 0.03 & $0.70 *$ & 0.51 & 1.00 & & & & & & & \\
\hline $\mathrm{Br}$ & -0.67 & -0.53 & -0.46 & 0.19 & -0.66 & -0.5 & 0.25 & 0.03 & 1.00 & & & & & & \\
\hline $\mathrm{Rb}$ & 0.5 & 0.35 & 0.66 & -0.14 & 0.48 & 0.60 & -0.50 & -0.03 & $-0.92 * *$ & 1.00 & & & & & \\
\hline $\mathrm{Sr}$ & -0.36 & -0.70 & 0.25 & 0.05 & $-0.72 *$ & -0.48 & -0.21 & -0.59 & 0.45 & -0.34 & 1.00 & & & & \\
\hline $\mathrm{Y}$ & 0.46 & 0.64 & 0.19 & 0.00 & $0.81^{*}$ & 0.60 & -0.03 & 0.40 & -0.57 & 0.57 & $-0.84 * *$ & 1.00 & & & \\
\hline $\mathrm{Zr}$ & $-0.92 * *$ & -0.46 & -0.55 & 0.52 & $-0.70 *$ & -0.07 & 0.07 & 0.37 & $0.82 *$ & -0.67 & 0.18 & -0.35 & 1.00 & & \\
\hline $\mathrm{Pb}$ & $0.96 * *$ & 0.42 & 0.48 & -0.66 & $0.70 *$ & 0.10 & 0.03 & -0.22 & $-0.78 *$ & 0.64 & -0.28 & 0.39 & $-0.96 * *$ & 1.00 & \\
\hline $\mathrm{Sn}$ & $-0.70 *$ & -0.35 & $-0.79 *$ & 0.59 & -0.59 & -0.19 & 0.39 & 0.22 & 0.57 & -0.66 & 0.28 & -0.61 & 0.66 & $-0.70^{*}$ & 1 \\
\hline
\end{tabular}

**Correlation significant at the 0,01 level (bilateral); *correlation significant at the 0,05 level (bilateral)

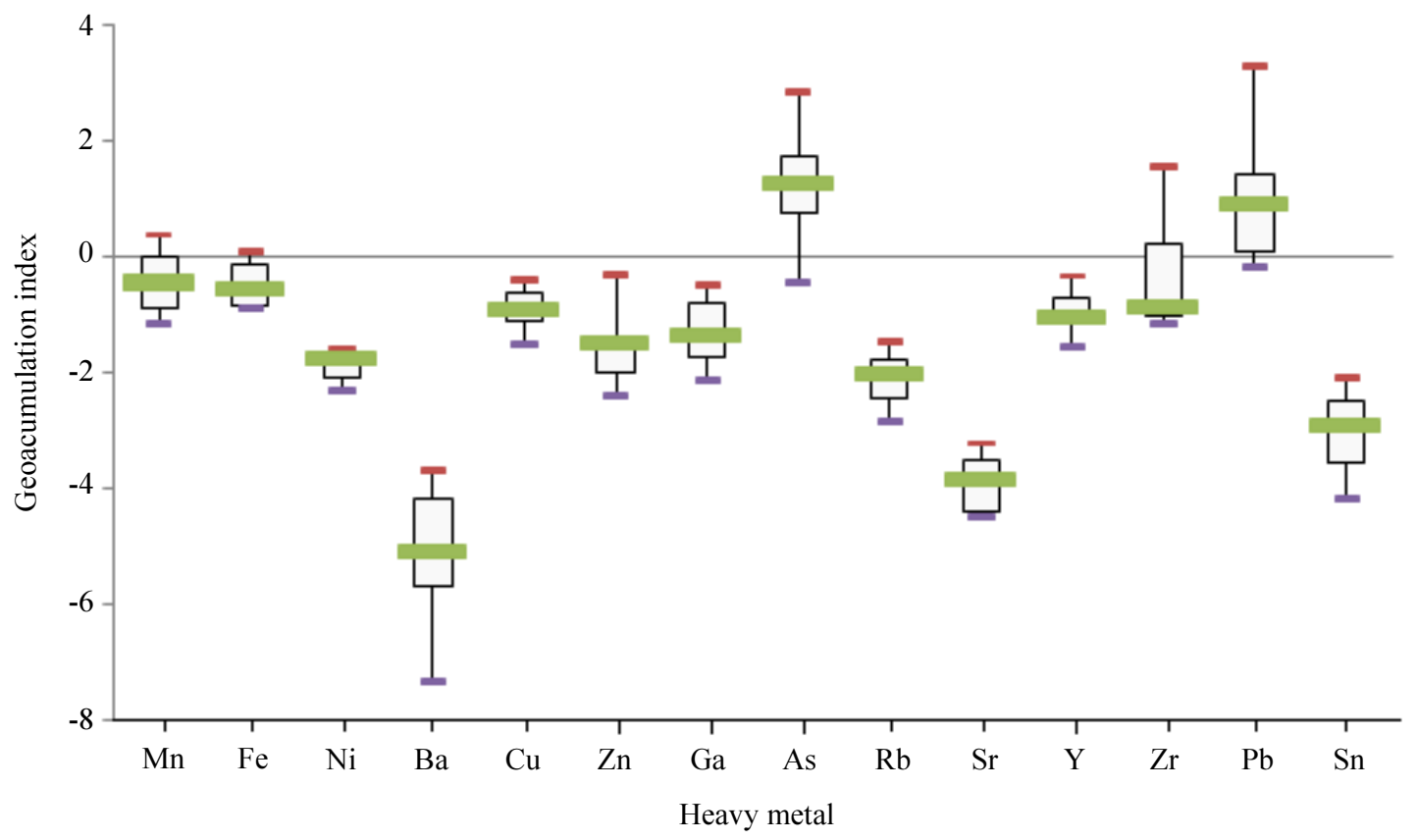

Fig. 4: Geoaccumulation index of heavy metals in soil samples of Bétaré Oya and Batouri 
However, it shows a strong positive correlation between $\mathrm{Cu} / \mathrm{Mn}$ (0.81), Y/Cu (0.81), $\mathrm{Zr} / \mathrm{Br}$ (0.82), $\mathrm{Pb} / \mathrm{Cu}(0.70)$ and $\mathrm{As} / \mathrm{Zn}(0.70)$ at $5 \%$ significant levels. While $\mathrm{Rb} / \mathrm{Br}$, $\mathrm{Sr} / \mathrm{Cu}, \mathrm{Y} / \mathrm{Sr}, \mathrm{Zr} / \mathrm{Mn}, \mathrm{Zr} / \mathrm{Cu}, \mathrm{Pb} / \mathrm{Br}, \mathrm{Pb} / \mathrm{Zr}, \mathrm{Sn} / \mathrm{Ni}$ and $\mathrm{Sn} / \mathrm{Pb}$ (Table 8) show a strong negative correlation.

The strong positive correlations between some elements signify that these elements come from the same activities and are probably governed by the same physicochemical processes (Emmanuel et al., 2014; Bai et al., 2011; Otari and Dabiri, 2015). Among the common anthropogenic sources, there are oil and fuel used for engines, the vestiges of abandoned machines, rusty empty barrels and plastic tins since these sources are noted to be contributing one or the pair correlated metals to the natural environment. However, their contribution is moderate.

\section{Conclusion}

The level of pollution in soils by heavy metals in the gold mining sites of Bétaré Oya and Batouri was evaluated using enrichment factors, contamination factors, degrees of contamination, pollution load index and geoaccumulation index. The study revealed that there were high concentrations of certain metals $(\mathrm{As}, \mathrm{Pb}$, $\mathrm{Mn}, \mathrm{Zr}$ and $\mathrm{Fe}$ ) in terms of enrichment of the soil from some sites. For instance, the enrichment factor of lead $(\mathrm{Pb})$ found for the site (BO4) in Betaré Oya indicates a significant enrichment and the geoaccumulation index for $\mathrm{Pb}$ in soil shows that this site is strongly polluted. With regard to the overall contamination of soils at the studied sites, the analysis indicates that contamination by the metals originated from anthropogenic sources. Based on the findings of this study, it is urgent to regulate mining activities in Cameroon to prevent environmental pollution, protecting people against harmful effects of toxic elements. For eliminating unacceptable health hazards from these metals and ensuring public and environmental safety; this study suggests the phytoremediation or the biogeosystem method (Kalinitchenko et al., 2016) as technics of regulation. The advantage of the biogeosystem method is to provide a long-term stable high productive soil evolution and environmentally safe waste recycling.

\section{Acknowledgement}

The Institute of Geological and Mining Research and the Centre for Atomic Molecular Physics and Quantum Optics are thanked for their support to carry out field work. XRF spectrometer and accessories were provided by the International Atomic Energy Agency through a technical cooperation project (CMR5014). The Abdus Salam International Centre for Theoretical Physics is acknowledged for its support (OEA-AC-71).

\section{Author's Contributions}

Dallou Guy Blanchard: Participated in all experiments, coordinated the data-analysis and contributed to the writing of the manuscript.

Ngoa Engola Louis: Participated in experimental planning and data-analysis interpretation.

Abdourahimi: Participated in all experiments, coordinated the data-analysis and helped in manuscript writing.

Bongue Daniel: Participated in experimental planning and data-analysis interpretation.

Saïdou: Coordinated all experimental planning and data interpretation and contributed to the writing of the manuscript.

Ndjana Nkoulou II Joseph Emmanuel: Participated in experimental planning and data-analysis interpretation.

Kankeu Boniface: Participated in experimental planning.

Kwato Njock Moïse Godfroy: Participated in experimental planning and critical data-analysis.

\section{Ethics}

Authors declare no conflict of interest.

\section{References}

Abdourahimi, S., W.Y. Fantong, F.T. Aka and N.M.G. Kwato, 2016. Environmental pollution by metals in the oil bearing Bakassi peninsula, Cameroon. Carpat. J. Eart. Environ. Sci., 11: 529-538.

Adedeji, O.H., Olayinka, O. Olufunmilayo, Nwanya and C. Franklin, 2014. Soil and water pollution levels in and around urban scrapyards. J. of Environ. Sci. Toxicol. Food Technol., 8: 60-68.

Abhijit, M. and M. Ramkrishna, 2017. Geochemical contamination in the mine affected soil of Raniganj Coalfielde a river basin scale assessment. Geosci. Frontiers, 30: 1-14. DOI: 10.1016/j.gsf.2017.10.011

Albert, N.F., B.C. Vivian and E.S. Cheo, 2012. Application of electrical resistivity and chargeability data on a GIS platform in delineating auriferous structures in a deeply weathered L ateritic Terrain, Eastern Cameroon. Int. J. Geosci., 3: 960-971. DOI: 10.4236/ijg.2012.325097

Auger, C., J. Lemire, V.P. Appanna and V.D. Appanna, 2013. Gallium in Bacteria: Metabolic and Medical Implications. In: Encyclopedia Metalloproteins, Kretsinger, R.H., V.N. Uversky and E.A. Permyakov (Eds.), Springer Publisher, pp: 800-807.

Arif, T.J., A. Mudsser, S. Kehkashan, A. Arif and C. Inho et al., 2015. Heavy metals and human health: Mechanistic insight into toxicity and counter defense system of antioxidants. Int. J. Mol. Sci., 16: 29592-29630. DOI: 10.3390/ijms161226183 
ATSDR, 2012. Toxicological profile for manganese. United States Department of health and Human Services, Public Health Service, Centers for Disease Control. Atlanta.

Azizi, M.H. and F. Azizi, 2010. Lead poisoning in the world and Iran. Int. J. Occup. Environ. Med., 1: 81-87.

Baby, J., S.R. Justin, E.T. Biby, P. Sankarganesh and M.V. Jeevitha et al., 2010. Toxic effect of heavy metals on aquatic environment. Int. J. Biol. Chem. Sci., 4: 939-952. DOI: 10.4314/ijbcs.v4i4.62976

Bai, J., B. Cui, B. Chen, K. Zhang and W. Deng et al., 2011. Spatial distribution and ecological risk assessment of heavy metals in surface sediments from a typical plateau lake wetland, China. Ecol. Modell., 222: 301-306.

DOI: 10.1016/j.ecolmodel.2009.12.002

Banat, K.M., F.M. Howari and A.A. Al-hamada, 2015. Heavy metals in urban soils of central Jordan. Environ. Res., 97: 258- 273.

Banu, Z., S.A. Chowdhury, D. Hossain and K. Nakagami, 2013. Contamination and ecological risk assessment of heavy metal in the sediment of Turag River, Bangladesh: An index analysis approach. J. Water Resource Protect., 5: 239-248. DOI: 10.4236/jwarp.2013.52024

Bignucolo, A., V.P. Appanna, S.C. Thomas, C. Auger and S. Han et al., 2013. Hydrogen peroxide stress provokes a metabolic reprogramming in Pseudomonas fluorescens: Enhanced production of pyruvate. J. Biotechnol., 167: 309-315.

DOI: $10.1016 /$ j.jbiotec.2013.07.002

Bost, M., S. Houdart, M. Oberli, E. Kalonji and J.F. Huneau et al., 2016. Dietary copper and human health: Current evidence and unresolved issues. J. Trace Elements Med. Biol., 35: 107-115. DOI: $10.1016 /$ j.jtemb.2016.02.006

Caeiro, S., M.H. Costa, T.B. Ramos, F. Fernandes and N. Silveria et al., 2015. Assessing heavy metal contamination in Sado Estuary sediment: An index analysis approach. Ecol. Indicators, 5: 151-169. DOI: 10.1016/j.ecolind.2005.02.001

Caspah, K., M. Manny and M. Morgan, 2016. Health risk assessment of heavy metals in soils from witwatersrand gold mining basin, South Africa. Int. J. Environ. Res. Public Health, 13: 663. DOI: 10.3390/ijerph13070663

Castro-Gonzalez, M.I. and M. Méndez-Armenta, 2008. Heavy metals: Implications associated to fish consumption. Environ. Toxicol. Pharmacol., 3: 263-271. DOI: 10.1016/j.etap.2008.06.001

Chiroma, T.M., R.O. Ebewele and F.K. Hymore, 2014. Comparative assessement of heavy metal levels in soil, vegetables and urban grey waste water used for irrigation in Yola and Kano. Int. Ref. J. Eng. Sci., 3: 1-9.
Crentsil, K. and E. Anthony, 2016. Heavy metals contamination and human health risk assessment around Obuasi gold mine in Ghana. Environ. Monit. Assess., 188: 261-261.

DOI: $10.1007 / \mathrm{s} 10661-016-5241-3$

CTFC, 2012. Plan simple de gestion de Produits Forestiers Non Ligneux (PFNL) Forêt communale de Batouri. Centre Technique de la Foresterie Communale, Cameroun.

Dallou, G.B., E.L. Ngoa, N.J.E. Ndjana II, Saïdou and S.Y.F. Tchuente et al., 2017. NORM measurements and radiological hazard assessment in the gold mining areas of Eastern Cameroon. Radiat. Environ. Med., 6: 22-28.

Emmanuel, A., S.J. Cobbina, D. Adomako, A.B. Duwiejuah and W. Asare, 2014. Assessment of heavy metals concentration in soils around oil filling and service stations in the Tamale Metropolis. Afri. J. Environ. Sci. Techn., 8: 256-266. DOI: $10.5897 / A J E S T 2014.1664$

Esser, B.K. and K.K. Turekian, 1993. The Osmium isotopic composition of the continental crust. Geochimica Cosmochimica Acta, 57: 3093-3104. DOI: 10.1016/0016-7037(93)90296-9

Ezekiel and A. Ayinde, 2015. Economic analysis of heavy metals pollution on soil, river and rice production in Nigeria. J. Emerg. Trends Econ. Manage. Sci., 6: 363-366.

Feifei, C., K. Linghao, Y. Liyuan and Z. Wei, 2015. Geochemical fractions and risk assessment of trace elements in soils around Jiaojia gold mine in Shandong Province, China. Environ. Sci. Pollut. Res. Int., 22: 13496-505. DOI 10.1007/s11356-015-4618-0

Fraga, C.G., 2005. Relevance, essentiality and toxicity of trace elements in human health. Molecular Aspects Med., 26: 235-244.

DOI: $10.1016 /$ j.mam.2005.07.013

Ghadimi, F., 2014. Assessment of the sources of chemical elements in sediment from Arak Mighan Lake. Int. J. Sediment Res., 29: 159-170. DOI: 10.1016/S1001-6279(14)60032-9

Halim, M.A., R.K. Majumder and M.N. Zaman, 2014. Paddy soil heavy metal contamination and uptake in rice plants from the adjacent area of Barapukuria coal mine, northwest Bangladesh. Arabian J. Geosci., 8: 3391-3401. DOI: $10.1007 / \mathrm{s} 12517-014-1480-1$

He, X., 2013. Yttrium, Biological Effects. In: Encyclopedia of Metalloproteins, Kretsinger, R.H., V.N. Uversky and E.A. Permyakov (Eds.), Springer, New York.

Iqbal, J., M.H. SHAH and G. Akhter, 2013. Characterization, source apportionment and health risk assessment of trace metals in freshwater Rawal Lake, Pakistan. J. Geochem. Explorat., 125: 94-101. DOI: $10.1016 /$ j.gexplo.2012.11.009 
Jiao, X., Y. Teng, Y. Zhan, J. Wu and X. Lin, 2015. Soil heavy metal pollution and risk Assessment in Shenyang Industrial District, Northeast China. PLoS One, 10: e0127736-e0127736.

DOI: 10.1371/journal.pone.0127736

Jochum, K.P., A.W. Hofmann and H.M. Seufert, 1993. Tin in mantle-derived rocks: constraints on Earth evolution. Geochim. Cosmochim. Acta, 57: 3585- 3595. DOI: 10.1016/0016-7037(93)90141-I

Kabir, M.I., H. Lee, G. Kim and T. Jun, 2011. Correlation assessment and monitoring of the potential pollutants in the surface sediments of Pyeongchang River, Korea. Int. J. Sediment Res., 26: 152-162. DOI: 10.1016/S1001-6279(11)60083-8

Khan, M.Z.H., M.R. Hasan, M. Khan, S. Aktar and K. Fatema, 2017. Distribution of heavy metals in surface sediments of the Bay of Bengal Coast. J. Toxicol., 2017: 9235764-9235764.

DOI: $10.1155 / 2017 / 9235764$

Kalinitchenko, V., B. Abdulmalik, A. Zarmaev, V. Startsev and V. Chernenko et al., 2016. Biogeosystem technique as the way to certainty of soil, hydrosphere, environment and climate, EGU General Assembly, Vienna. Geophys. Res. Abs., 18: EGU2016-3419.

Krika, A. and F. Krika, 2017. Evaluation of the status of heavy metal pollution in surface water and sediments of the Nil River (North Eastern Algeria). Pollution, 3: 301-310. DOI: 10.7508/PJ.2017.02. 011

Likuku, A.S., B. Khumoetsile, M. Molawa and G.K Gaboutloeloe, 2013. Assessment of heavy metal enrichment and degree of contamination around the copper-nickel mine in the Selebi Phikwe Region, Eastern Botswana. Environ. Ecol. Res., 1: 32-40. DOI: 10.13189/eer.2013.010202

Lucchini, R.G., M. Aschner, Y. Kim and M. Saric, 2015. Manganese. In: Handbook on the Toxicology of Metals, Nordberg, G.F., B.A. Fowler and M. Nordberg (Eds.), Academic Press Publications, UK, pp: 975-1011.

Mmolawa, K.B., A.S. Likuku and G.K. Gaboutloeloe, 2011. Assessment of heavy metal pollution in soils along major roadside areas in Botswana. African J. Environ. Sci. Technol., 5: 186-196.

Mo, C., L. Wenxi, H. Zeyu, Z. Yu and J. Xue et al., 2016. Heavy metal pollution in soil associated with a large-scale cyanidation gold mining region in southeast of Jilin, China. Environ. Sci. Pollut. Res., 24: 3084-3096. DOI: 10.1007/s11356-016-7968-3

Moore, F., G. Forghani and A. Qishlaqi, 2009. Assessment of heavy metal contamination in water and surface sediments of the Maharlu saline Lake, SW Iran. Iran. J. Sci. Technol., Trans. A, 33: 43-55.

Müller, G., 1969. Index of geoaccumulation in sediments of the Rhine River. Geojournal, 2: 108-118.
Mushtaha, A., E. Abdalla, E. Jamal and S. Magboul, 2017. Influence of the artisanal gold mining on soil contamination with heavy metals: A case study from Dar-Mali locality, North of Atbara, River Nile State, Sudan. Eurasian J. Soil Sci., 6: 28-36. DOI: $10.18393 /$ ejss.284261

Nazari, E. and M. Razmara, 2014. Evaluation of the heavy metal contaminations in water resources in ophiolitic complex of Pangi area, (Kadkan, NW Torbat Hydarieh, Iran). J. Middle East Applied Sci. Technol., 6: 152-156.

Nowrouzi, M. and A. Pourkhabbaz, 2014. Application of geo-accumulation index and enrichment factor for assessing metal contamination in the sediments of Hara Biosphere Reserve, Iran. Chem. Speciat. Bioavailability, 26: 99-105. DOI: $10.3184 / 095422914 X 13951584546986$

Otari, M. and R. Dabiri, 2015. Geochemical and environmental assessment of heavy metals in soils and sediments of Forumad Chromite mine, NE of Iran. J. Min. Environ., 6: 251-261.

Pawan, K.B, 2012. Heavy Metals in Environment. 1st Ed. Lambert Academic Publishing GmbH and Co. KG, Saarbrucken, Germany, ISBN-13: 978-3-659-15133-0.

Penaye, J. and J.V. Hell, 2013. Abandoned artisanal gold mining sites of Eastern Cameroon: Environmental problems and Cameroon regulation. Institute for Geological and Mining Research. Report, Yaounde, Cameroun.

Qian, L., J. Hongbing, Q. Fei, T. Lei and G. Xinyue et al., 2014. Sources and the distribution of heavy metals in the particle size of soil polluted by gold mining upstream of Miyun Reservoir, Beijing: Implications for assessing the potential risks. Environ. Monit. Assess., 186: 6605-6626. DOI: $10.1007 / \mathrm{s} 10661-014-3877-4$

Ran, X., W. Shuang, L. Ronghua, J.W. Jim and Z. Zengqiang, 2017. Soil heavy metal contamination and health risks associated with artisanal gold mining in Tongguan, Shaanxi, China. Ecotoxicol. Environ. Safety, 141: 17- 24. DOI: $10.1016 /$ j.ecoenv.2017.03.002

Rastmanesh, F., F. Moore, M.K. Kopaei, B. Keshavarzi and M. Behrouz, 2010. Heavy metal enrichment of soil in Sarcheshmeh copper complex, Kerman Iran. Environ. Eart. Sci., 62: 329-336. DOI: $10.1007 / \mathrm{s} 12665-010-0526-2$

Sabah, A., A.A.W. Fouzul and A.M. Fouzul, 2012. The environmental impact of gold mines: pollution by heavy metals. Cent. Eur. J. Eng., 2: 304- 313. DOI: $10.2478 / \mathrm{s} 13531-011-0052-3$

Sadhu, K., K. Adhikari and A. Gangopadhyay, 2012. Assessment of heavy metal contamination of soils in and around open cast mines of Raniganj Area, India. Int. J. Environ. Eng. Res., 1: 77-85. 
Salati, S. and F. Moore, 2010. Assessment of heavy metal concentration in the Khoshk River water and sediment, Shiraz, Southwest Iran. Environ. Monit. Assess., 164: 677- 689. DOI: $10.1007 / \mathrm{s} 10661-009-0920-\mathrm{y}$

Shahid, M., E. Ferrand, E. Schreck and C. Dumat, 2013. Behavior and impact of zirconium in the soil-plant system: Plant uptake and phytotoxicity. Rev. Environ. Contaminat. Toxicol., 221: 107-127. DOI: 10.1007/978-1-4614-4448-0 2

Sijin, L., W. Yeyao, T. Yanguo and Y. Xuan, 2015. Heavy metal pollution and ecological risk assessment of the paddy soils near a zinc-lead mining area in Hunan. Environ. Monit. Assess., 187: 627-627. DOI: 10.1007/s10661-015-4835-5

Smuc, N.R., T. Serafimovski, T. Dolenec, M. Dolenec and P. Vrhovnik et al., 2015. Mineralogical and geochemical study of Lake Dojran sediments (Republic of Macedonia). J. Geochem. Explor., 150: 73-83. DOI: 10.1016/j.gexplo.2014.12.019

Suh, E.C., B. Lehmann and G.T. Mafany, 2006. Geology and geochemical aspects of lode Gold mineralization at Dimako-Mboscoro, SE Cameroon. Geochem. Expl. Envir. Anal., 6: 295-309. DOI: $10.1144 / 1467-7873 / 06-110$

Sujeenthar, T., A. Azhar, P.A. Varun and D.A. Vasu, 2017. Decontamination of Multiple-Metal Pollution by Microbial Systems the Metabolic Twist. In: Handbook of Metal-Microbe Interactions and Bioremediation, Das, S. and H.R. Dash (Eds.), Springer, ISBN-10: 1498762425, pp: 155-167.

Tariq, J., A. Nasir and M. Azhar, 2018. Heavy metals contamination and ecological risk assessment in surface sediments of Namal Lake, Pakistan. Pol. J. Environ. Stud., 27: 681-688. DOI: $10.15244 /$ pjoes/75815

Taylor, S.R. and S.M. Mclennan, 1985. The Continental Crust: Its Composition and Evolution. 1st Edn., Blackwell Scientific Publications, Oxford.

Tehna, N., F.D. Nguene, J. Etame, E.J.M. Medza and T.S. Noa et al., 2015. Impending pollution of betare oya opencast mining environment (Eastern Cameroon). J. of Environ. Sci. and Eng. B, 4: 37-46. DOI: $10.17265 / 2162-5263 / 2015.01 .006$
Tobias, I., E. Ndubuisi, A.N. Ezejiofor, A.C. Udebuani and E.U. Ezeji et al., 2013. Environmental metals pollutants load of a densely populated and heavily industrialized commercial city of Aba, Nigeria. J. Toxicol. Environ. Healt., 5: 1-11. DOI: $10.5897 /$ JTEHS 11.081

USEPA, 2013. Toxicity Relationship Analysis Program (TRAP) version 1.22 United States Environmental Protection Agency, Mid-Continent Ecology Division. Washington D.C., USA.

Verdejo, J., R. Ginocchio, S. Sauve, P. Mondaca and A. Neaman, 2016. Thresholds of copper toxicity to lettuce in field-collected agricultural soils exposed to copper mining activities in Chile. J. Soil Sci. Plant Nutr., 16: 154-158.

DOI: $10.4067 / \mathrm{S} 0718-95162016005000011$

WHO, 1996. Trace Elements in Human Nutrition and Health. Geneva, Switzerland, ISBN-13: 9241561734 , pp: 361 .

Yakeu, S.A.F., T. Njanko, E. Njonfang, E. Errami and P. Rochette et al., 2016. Transpressional graniteemplacement model: Structural and magnetic study of the Pan-African Bandja granitic pluton (West Cameroon). J. Earth Syst. Sci., 125: 179-202.

Yongming, H., D. Peixuan, C. Junji and E.S. Posmentier, 2006. Multivariate analysis of heavy metal contamination in urban dusts of Xi'an, Central China. Sci. Total Environ., 355: 176-186. DOI: 10.1016/j.scitotenv.2005.02.026

Zahra, A., M.Z. Hashmi, R.N. Malik and Z. Ahmed, 2014. Enrichment and geo-accumulation of heavy metals and risk assessment of sediments of the Kurang Nallah, feeding tributary of the Rawal lake, reservoir, Pakistan. Sci. Total Environ., 925: 470-471. DOI: 10.1016/j.scitotenv.2013.10.017

Zahran, M.A.E., Y.A. El-amier, A.A. Elnaggar, H.A.E. Mohamed and M.A.E. El-alfy, 2015. Assessment and Distribution of heavy metals pollutants in Manzala Lake, Egypt. J. Geosci. Environ. Protect., 3: 107-122. DOI: 10.4236/gep.2015.36017 